\title{
Meta-heuristic optimization methods applied to renewable distributed generation planning: A review
}

\author{
Ali Tarraq $^{1, *}$, Faissal Elmariami $^{1}$, Aziz Belfqih ${ }^{1}$, and Touria Haidi $^{2,3}$ \\ ${ }^{1}$ Energy and Electrical Systems Laboratory , National Superior School of Electricity and Mechanics (ENSEM), Hassan II University of \\ Casablanca, B.P 8118, Oasis, Casablanca, Morocco. \\ ${ }^{2}$ Networks, Informatics, Telecommunications and Multimedia Laboratory, High School of Technology (EST), Hassan II University of \\ Casablanca, B.P 8012, Oasis, Casablanca, Morocco. \\ ${ }^{3}$ Automatic, Electrical Systems and Renewable Energies Laboratory, Hassania School of Public Works (EHTP), Hassan II University of \\ Casablanca, B.P 8108, Oasis, Casablanca, Morocco.
}

\begin{abstract}
Due to its proven efficiency and computational speed, the most recent developed meta-heuristic optimization methods are widely used to better integrate renewable distributed generation (RDG) into the electricity grid. The main objective of this paper is to obtain a better knowledge of current trends in metaheuristics applied to optimally integrate RDGs to the distribution network. This is a review of well known meta-heuristic approaches, used to solve the problem of optimal renewable distributed generation allocation planning (ORDGAP). In this context, some research gaps were mentioned, and recommendations were proposed to expand the scope of research in this field.
\end{abstract}

\section{Introduction}

Due to climate change, resulting from the increase in global warming and greenhouse gas emissions, in addition to the enormous increase in the fuel price, it becomes imperative to replace fossil fuels energy sources with renewable and sustainable ones. As a result, many countries, particularly developed ones, are moving towards electricity production from renewable sources, and are limiting the production of fossil fuel based thermal power plants. As shown in

Fig. 1, electricity generation from renewable sources in the United States is beginning to approximate that from coal [1].

This is certainly the result of the recent interest in renewable distributed generation (RDG) as a sustainable solution for the development of the future electricity system, and the supply of remote areas. The high penetration of RDG into the transmission and distribution electricity grid (T\&D) has two main advantages. On the one hand, it contributes significantly to reducing the consumption of dirty energy (essentially energy coming from the combustion of fossil fuels), and on the other hand, it considerably increases the security of the power supply for the end customer.

According to [2], RDGs can be defined as "a smallscale generation units harnessing renewable energy resources (such as sun, wind, water, biomass and geothermal energy), at or near the point of use, where the users are the producers-whether individuals, small businesses and/or a local community. If the small-scale generation plants are also connected with each other (to share the energy surplus), they become a Renewable Local Energy Network, which may in turn be connected with nearby similar networks".

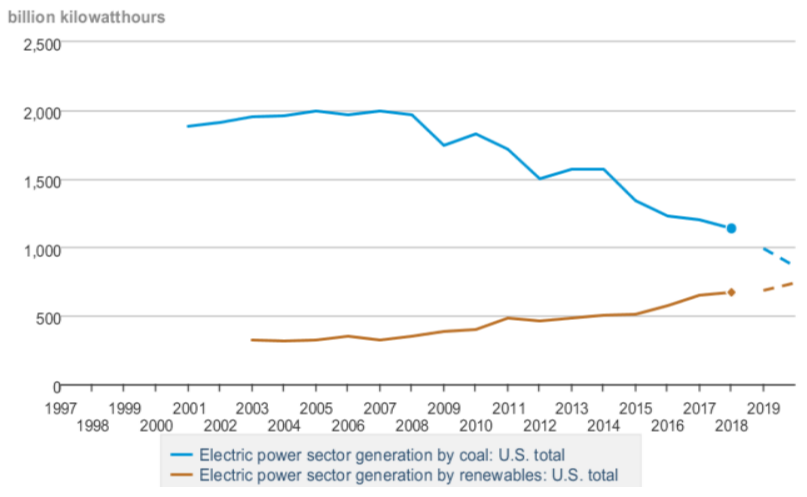

Fig. 1. Electric power supply sector net generation from United States [1].

According to $[3,4]$, the high penetration level of RDG units into the T\&D electricity grid, has several technical, economic and environmental drawbacks [5]. Many studies have shown that this issue can only be solved by a well conducted optimization study. Nevertheless, the success of any optimization study depends on several criteria, including the type of the optimization problem, the choice of the appropriate method, and the perfect understanding of the algorithm's operating mechanism, as well as its implementation [6].

From an optimization standpoint, the ORDGAP is generally classified as a non-linear, highly constrained, multi-objective, mixed-integer, multimodal optimization

*Corresponding author: ali.tarraq@ensem.ac.ma 
problem, where it is very difficult to find a quasi global solution [7].

According to [8], this problem consists in determining a set of DG decision variables, such as size, bus location or site, power factor (PF), number and type, to minimize or maximize a set of objective functions, e.g. power losses minimization and voltage profile improvement. According to [9], the ORDGAP is the search for the appropriate size, placement and the wellcoordinated control of an optimal number of DGs in the distribution system.

From a technical and economic perspective, effective integration of the RDG system is impossible without adequate resource allocation and system capacity planning. In this context, the availability of renewable resources on site, dynamic variation and growth in load demand, as well as the cost factors, technical efficiency and carbon balance of the various power generation technologies must be seriously considered.

In order to minimise the overall cost of RDG unit's integration, while improving the characteristics of the distribution network, an effective approach for planning optimization is essential for research developments, decision-makers and Distribution Network Operators (DNOs). Accordingly, the most recent studies [10,11], show that these methods can be classified into five categories: mathematical approaches, heuristic methods, meta-heuristics, analytical methods and hybrid approaches.

Due to its proven performance and efficiency in finding a good quality of the optimal or near-optimal solution, as well as its ability to analyse large-scale electrical distribution systems and the richness of their knowledge base, meta-heuristic methods are the most widely used and recommended by most researchers. In addition, this type of method has proven its ability to solve constrained multi-objective optimisation problems (MOOP), as is the case with the RDG allocation planning $[12,13]$.

According to the authors' knowledge, there is no recent research paper in the literature that provides a comprehensive review of this type of study. So this article aims to examine these types of methods as they are applied to the planning of RDGs, and is organised as follows: Section 2 summarises the most popular articles that review recent trends and published work on the application of different optimisation techniques to solve the problem of the optimal location and size of RGD units in the distribution network. The third section aims to present the most needed RGD planning tools: types, configurations, common formulation, objectives and constraints. The fourth section provides an overview of recent peer-reviewed papers that address the ORDGAP problem, using the meta-heuristic approach.

\section{Literature Review}

In the recent literature, various meta-heuristic methods have been successfully used to solve the ORDGAP problem. Using the Scopus database, Fig. 2 presents a histogram of published papers on this topic over the last decade and regressed to 2022. In all, there are 110 journal papers, 23 of which are full literature reviews. As can be seen, the number of articles published increased significantly in 2019, indicating an improving trend. For this reason, reviewing that type of method when applied to the ORDGAP problem has become the natural motivation of this review paper.

The choice of the suitable optimization method is often linked to researchers' knowledge of the different optimization methods available in the literature, as well as those used to optimize the planning and the integration of RDG units into the T\&D grid. But since these optimization methods are in full development, this choice can efficiently be done through the most recent, specialized, exhaustive and relevant reviews in the field of DG's optimization.

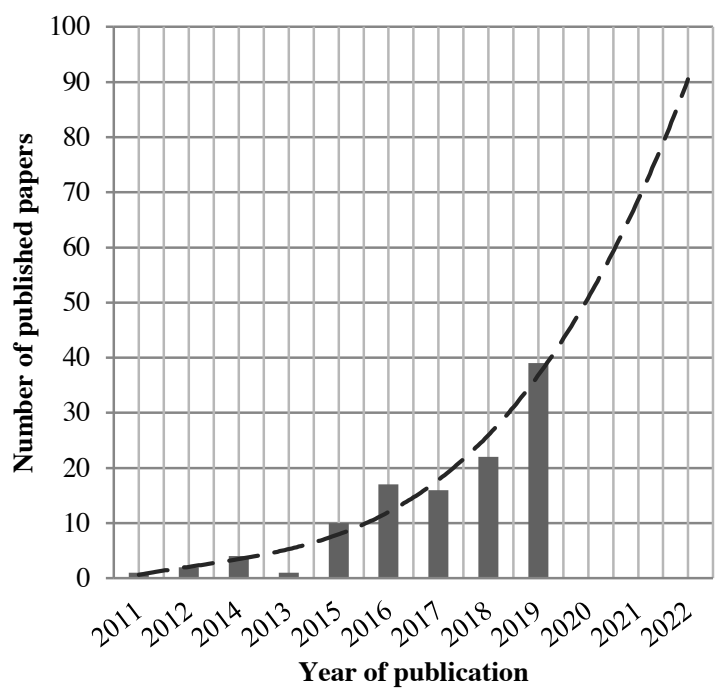

Fig.2. Number of papers using meta-heuristics for solving the ORDGAP problem during the last 10 years.

In the recent five years, many reviews paper are published for examining the ORDGAP tools. In [14], the authors propose a literature review that brings together the various existing optimization methods applied to the planning and integration of distributed generation from renewable energy sources. The focus is on solving the problem of the location and sizing of distributed generation units (DGUs), given the enormous annual growth in the number of articles published in this field. The authors in [9], present a well-detailed summary of the studies carried out on improving the performance indices of the distribution network, by integrating the same type of DG units. For that purpose, they reviewed the different load models of electricity distribution networks based on the total minimum losses in active power, and the total minimum consumption of MVAs in relation to the main substations.

Besides, the authors in [15] propose a literature review of the uncertainty modelling methods used to model the uncertain parameters associated with RDGs, as well as the methods used for the optimal planning and integration of DGs into the distribution network. Reference [16] is an exhaustive literature review of optimization methods and the most significant and widely used objective functions and constraints in 
literature related to the ORDGAP. In this review paper, the optimal allocation of DGs has been examined and presented with a particular focus on mathematical models and widely used techniques. A brief analysis of the related studies was also conducted with respect to the objectives and constraints adopted. The authors in [6] give a critical review of the numerical and mathematical optimization techniques adopted in literature. The comparative study and judgment made on the efficiency of each method is based on the methodology of input data collection and generation, the design of the system configuration, the model formulation and the techniques chosen for system optimization.

As a common result, several approaches are being proposed to carry out the (ORDGAP) problem. Some of these approaches are based on classical or conventional methods, like non linear programming NLP, and mixed integer non linear programming MINLP, which are more suited for solving special cases in power system applications. However, they are not adapted for well addressing a combinatorial optimization problem, such as the ORDGAP problem, where the majority of parameters are under uncertainties.

\section{RDG Planning Tools}

\subsection{RDG's types and possible system configurations}

\subsubsection{RDG's types:}

The type of the RDG is one of the most important decision variables of the ORDGAP. However, since the units of the RDG belong to the DG family, it is first necessary to review the usual classifications of the latter.

In order to classify DGs, several criteria can be taken into account. DGs can be classified according to their power range (micro, small, medium and large) [17]. It can be, also classified by the technology adopted in two categories: traditional generator e.g. low speed turbines, diesel engines, micro-turbines etc, and non-traditional generator e.g. electrochemical devices, storage devices and renewable devices which is usually called RDG $[18,19]$. Generally, For the optimal distributed generation planning resolution problems based on: losses reduction, power factor, and loadability enhancement, the most suitable classification of DGs was introduced by Hung et al., and adopted by many authors [15,20-22]. This classification proposes four major DG types based on their electrical ratings in terms of power factor, as follows:

-Type 1: DG capable of injecting P only, e.g. PV panels, micro turbines, fuel cells, usually integrated to the main grid.

-Type 2: DG capable of injecting Q only, e.g. synchronous compensators based gas turbine.

-Type 3: DG capable of injecting both $\mathrm{P}$ and Q, e.g. synchronous machine (cogeneration, gas turbine, etc.).

-Type 4: DG capable of injecting P but consuming Q, e.g. induction generators based wind farms.
Accordingly, RDG units can only be a Type 1 or Type 4. From a technological standpoint, the RDG belongs to the class of non-traditional DGs and it includes: photovoltaic, geothermal, wind turbine, small hydro or any other renewable energy solution. It can be incorporated with battery energy storage systems (BESS), shunt capacitors, synchronous condensers, as well as Distributed Static Compensator (DSTATCOM) [23-26].

\subsubsection{RDG's system configurations:}

Depending on the type of links between the source, the storage system and the electrical load being supplied, the RDG takes several configurations. This link can be DC only, AC only or mixed AC/DC. The chosen configuration identifies the number, size and type of converters, number of unidirectional and bidirectional links, and the type of storage systems to be installed [6].

Given the importance of being connected with other DGs, the final configuration must take into account the bi-directionality of the power. The figure shows the three possible configurations of a DG, assuming that it can be an intelligent microgrid that offers the possibility of being connected with other neighbouring microgrids.

In future power grid, smartness is one of the most recommended criteria. This shows how important the interconnection of the DGs installed in the grid is. For this reason, the final configuration of the selected DG must take into account the bi-directionality of the energy flow. These configurations, as shown in Fig. 3Error! Reference source not found., assume that DG unit can be a smart microgrid that offers the possibility to be connected to other neighbouring microgrids. Thus, to have this possibility it would be more convenient to consider that the $\mathrm{AC}$ loads or the $\mathrm{AC}$ generators can also be neighbouring micro-grids.

\subsection{Common mathematical RDGP's problem formulation}

As in many previous studies, the problem of ORDGAP was often addressed in a multi-objective approach. Mathematically, multi-objective optimisation (MOO) can be defined as an optimisation problem that deals with "a vector of decision variables" meeting constraints and optimising a vector function where each element is an objective function. In engineering, most optimisation problems contain conflicting objective functions, e.g. technical functions with financial functions.

Coello define a quite relevant formulation of MOO's problems, assuming e inequality constraints and $\mathrm{d}$ equality constraints, such as $[12,27]$ :

$\operatorname{Min} \bar{f}_{k}\left(\bar{x}_{n}, \bar{y}_{m}\right)=\left[o_{l}\left(\bar{x}_{n}, \bar{y}_{m}\right), o_{2}\left(\bar{x}_{n}, \bar{y}_{m}\right), \ldots, o_{k}\left(\bar{x}_{n}, \bar{y}_{m}\right)\right]^{\top}$

Subject to

$\begin{array}{ll}g_{i}\left(\bar{x}_{n}, \bar{y}_{m}\right)=0, & i=1,2, \ldots, d \\ h_{i}\left(\bar{x}_{n}, \bar{y}_{m}\right) \leq 0, & i=1,2, \ldots, e\end{array}$ 
Where $\bar{x}_{n}=\left[x_{1}, x_{2}, \ldots, x_{n}\right]^{\top}$ is a vector of $\mathrm{n}$ independent decision variables or control variables, and $\bar{y}_{m}=\left[y_{1}, y_{2}, \ldots, y_{m}\right]^{\top}$ is a vector of $m$ dependant decision variables or state variables. The constraints determine de "feasible region" $F$ and any point $\bar{x}_{n} \in F$ gives a "feasible solution" where $g_{i}\left(\bar{x}_{n}, \bar{y}_{m}\right)$ and $h_{i}\left(\bar{x}_{n}, \bar{y}_{m}\right)$ are the constraints imposed on decision variables. The vector function $\bar{f}_{k}\left(\bar{x}_{n}, \bar{y}_{m}\right)$ in (1) is a set of $k$ objective functions $o_{i}\left(\bar{x}_{n}, \bar{y}_{m}\right)$ for $i=1, \ldots, k$ representing $k$ non-commensurable criteria.

For more clarity on the decision variables, taking the example of the optimal power flow (OPF) [11,28]. Control variables control the power flow, while the state variables describe the power system state, such as: $\bar{x}_{n}=\left[P_{2} \ldots P_{N G}, V_{1} \ldots V_{N G}, T_{S_{1}} \ldots T_{S_{N G}}, Q_{1} \ldots Q_{N C}\right]^{\top}$

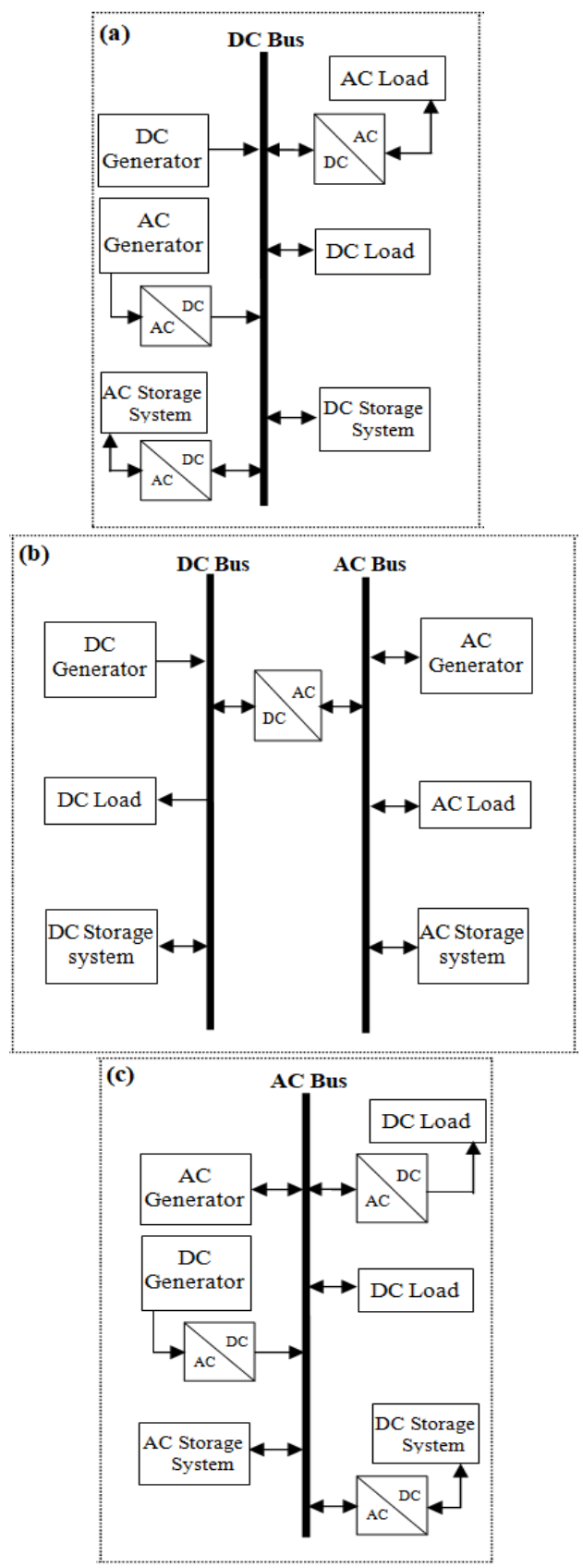

Fig. 3. General DG's configurations of (a) DC-Bus (b) Mixed AC/DC-Bus and (c) AC-Bus. where $\mathrm{P}_{\mathrm{NG}}$ is the generated power at all generation buses except the slack bus, $\mathrm{V}_{\mathrm{NG}}$ is the voltage at generation buses, $\mathrm{T}_{\mathrm{SNT}}$ is the transformers tap-setting, and $\mathrm{Q}_{\mathrm{NC}}$ is the shunt VAR compensators. NG, NT, and NC are the total number of generators, transformers and shunt VAR compensations, respectively.

$\bar{y}_{n}=\left[P_{1}, V_{L 1} \ldots V_{L N L}, Q_{1} \ldots Q_{N G}, S_{l_{1}} \ldots S_{l_{N T L}}\right]^{\top}$

where $\mathrm{NG}, \mathrm{NT}$, and $\mathrm{NC}$ are the total number of generators, transformers and shunt VAR compensations, respectively. $\mathrm{Q}_{\mathrm{NC}} \mathrm{P}_{1}$ is the generated power at the slack bus, $\mathrm{V}_{\mathrm{L}}$ is the voltage at load buses, $\mathrm{Q}_{\mathrm{NG}}$ is the reactive power of all generation units, and $\mathrm{S}_{1}$ is the loading of transmission lines. $\mathrm{N}_{\mathrm{TL}}$ and $\mathrm{N}_{\mathrm{L}}$ are the transmission line numbers and load bus numbers, respectively.

In the case of RDGA, the control variables can be the location (or siting), and the generated power (or sizing) of each RDG unit. While the state variables can be the voltage magnitude and the nodal phase angle of each bus of the system [29].

\subsection{Most common objective-functions}

According to [16] the most common objective functions used in RDGA problem, can be classified into three categories; technical objectives, financial objectives or environmental objectives.

Table 1.The objective functions used for the problem of optimal DG planning.

\begin{tabular}{|c|c|}
\hline Functions to be minimized & Functions to be maximized \\
\hline 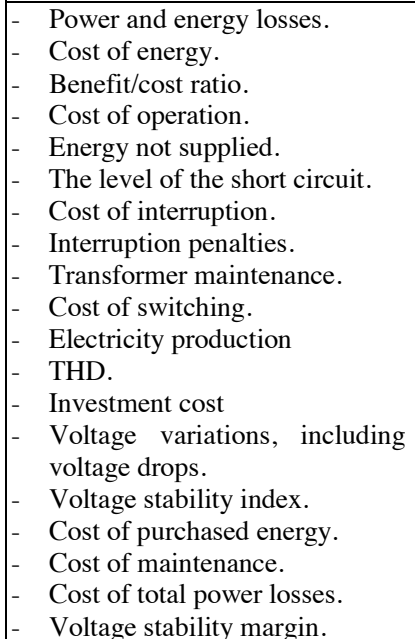 & 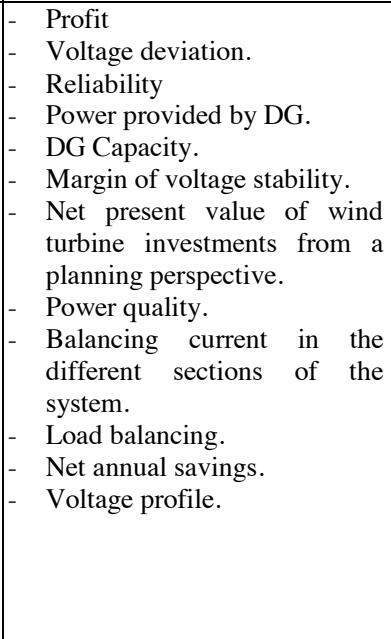 \\
\hline
\end{tabular}

Out of all the objective functions summarized in Table 1, the most common are; minimization of active power losses, reactive power losses, electric energy losses, improvement of voltage profile, and maximization of cost savings [8].

The number of these functions varies from year to year. The choice among these objectives, as well as their preponderance, is one of the most decisive criteria for the success of any RDG's allocation optimization study. 


\subsection{Most common constraints}

Usually, the RDGA optimization problem is considered as a constrained non-linear, and a complex combinatorial analysis. In general, the set of constraints can be divided into two categories; equality constraints and inequality constraints. But in the case of RDGA problem, these constraints can either be related to the conservation of the electricity grid, or to the capacity limitations of the utilities.

On this basis, Table 2 summarizes the most commonly constraints in the literature, used to address the RDGA optimization problem.

Table 2. The most common RDGA constraints.

\begin{tabular}{|c|c|c|c|c|c|}
\hline Power system conservation constraints & Equal & Inequal & Utilities capacity limitations constraints & Equal & Inequal \\
\hline $\begin{array}{l}\text { - Power balance } \\
\text { - Node voltage } \\
\text { - Line current } \\
\text { - Power factor limitation of RDG units. } \\
\text { - Number o switchable lines } \\
\text { - Thermal limit } \\
\text { - DG penetration limits. } \\
\text { - Active and reactive load balance. } \\
\text { - power transformer thermal rating }\end{array}$ & $\mathrm{x}$ & $\begin{array}{l}\mathrm{x} \\
\mathrm{x} \\
\mathrm{x} \\
\mathrm{x} \\
\mathrm{x} \\
\mathrm{x} \\
\mathrm{x} \\
\mathrm{x}\end{array}$ & $\begin{array}{l}\text { - Short circuit current. } \\
\text { - Capacity of intertie power } \\
\text { - Number of RDGs. } \\
\text { - Power generation limit. } \\
\text { - DG capacity limit } \\
\text { - Total harmonic distortion (THD) limits }\end{array}$ & $\mathrm{x}$ & $\begin{array}{l}\mathrm{x} \\
\mathrm{x} \\
\mathrm{x} \\
\mathrm{x} \\
\mathrm{x}\end{array}$ \\
\hline
\end{tabular}

\section{Meta-heuristics applied to ORDGAP problem}

Usually, ORDGAP is a complex combinatorial analysis. In fact, for such type of problems, heuristic methods have been established since 1940s. Heuristics combines trial and error solutions for complex problems within real time limits. But, as the complexity of the problem increases, especially with the occurrence of uncertain parameters, more complicated optimization approaches are required. For this reason, meta-heurstic methods have been developed since the 1980s. These approaches simulate the natural and social behaviors of some organisms, and the modalities of their development and adaptation to their environment [14].

Meta-heuristic approaches are often established through the mathematical formulation of living beings behaviors, physical phenomena, social behaviors and biological laws. Usually, in-depth observation and accurate understanding of these phenomena, often results in very advanced algorithms that are suitable for solving many complex and combinatorial engineering problems. The most popular and widely used of these algorithms are Genetic Algorithm (GA) and Particle Swarm Optimization (PSO). GA simulates the genetic evolution of living organisms, and includes five steps; initial population, fitness function, selection, crossover and mutation. PSO algorithm, simulates the propagation of swarms of migratory birds, and depends on random propagation.

From the literature, these meta-heuristic methods are fundamentally classified into two categories: trajectorybased (single-based) and population-based methods. The major difference between these two classes is the number of provisional solutions used at each step, or iterative, of the algorithm. On one hand, a trajectorybased method, e.g. Hill Climbing (HC), Tabu Search (TS), Simulated Annealing (SA) and Explorative Local Search (ELS) methods, starts with a single initial solution. At each level of the search, the currently available solution is replaced by another (often the best) solution found in its proximity. Thus, it is not surprising that meta-heuristic methods based on trajectories quickly find an optimal local solution. In the other hand, population-based algorithms use a set of solutions (i.e. a population of solutions). The initial population is produced randomly and then refined iteratively until the best one. At each iteration, some individuals in the population are replaced by newly generated ones, resulting in a new generation, which are often those whose characteristics are best suited to solving the problem. These approaches are called exploration-based methods because their main capacity lies in diversification in the research space $[13,30]$.

Population-based methods are more suitable for combinatorial optimization problems. These methods include evolutionary algorithms, swarm intelligence and physics-based algorithms, which have received considerable attention in recent years, mainly due to rapid advances in computer technology and the development of user-friendly and open source software [13]. A simplified classification of different metaheuristic methods is depicted in Fig. 4.

Many scientific contributions are being developed for a better ORDGAP, and others have been successfully accomplished. The vast majority of these studies have addressed the issue of ORDGAP, by improving or using one of the meta-heuristic approaches proposed in the literature. Table 3 summarises the recent and the most relevant of these scientific contributions, with their results.

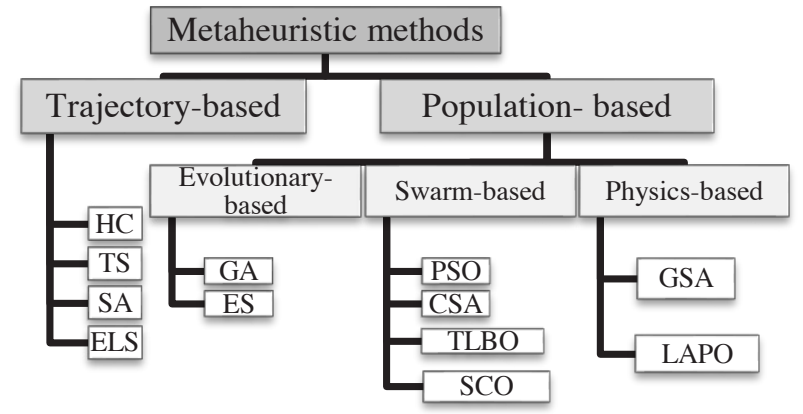

Fig. 4. Classification of metaheuristic methods. 
Table 3. Summary of recent peer reviewed articles dealing with the ORDGAP problem

\begin{tabular}{|c|c|c|c|c|c|c|c|c|}
\hline Ref & $\begin{array}{l}\text { Proposed } \\
\text { algorithm }\end{array}$ & Compared to & Objective functions & \begin{tabular}{|c|} 
DG type / number / \\
configuration
\end{tabular} & Network & results & $\begin{array}{c}\text { Decision } \\
\text { variables }\end{array}$ & Uncertainties \\
\hline [29] & $\begin{array}{l}\text { Hybrid GOA and } \\
\text { CSA }\end{array}$ & $\begin{array}{l}\text { PSO, GA, CS, } \\
\text { GOA, } \\
\text { SSA }\end{array}$ & $\begin{array}{l}\text {-Power loss } \\
\text {-Voltage profile } \\
\text {-Voltage stability }\end{array}$ & $\begin{array}{l}\text { Variable and constant } \\
\text { power load, } \\
\mathrm{PF}_{1}=1 \\
\mathrm{PF}_{2}=0,9 \text { (lagging) }\end{array}$ & $\begin{array}{l}33 \text { bus }-69 \\
\text { bus }\end{array}$ & $\begin{array}{l}\text { Proposed }>\text { SSA } \\
>\text { LSA }\end{array}$ & $\begin{array}{l}\text { Site } \\
\text { Size } \\
\text { Number }\end{array}$ & - \\
\hline [31] & $\begin{array}{l}\text { CTLBO } \\
\text { (Comprehensive } \\
\text { TLBO) }\end{array}$ & $\begin{array}{l}\text { TLBO, } \\
\text { QOTLBO } \\
\text { (Quasi- } \\
\text { Oppositional } \\
\text { TLBO) }\end{array}$ & $\begin{array}{l}\text {-Loss reduction } \\
\text {-Voltage profile } \\
\text {-Annual energy } \\
\text { savings }\end{array}$ & $\begin{array}{l}\text { 3DGs } \\
\mathrm{PF}=1 \\
\text {-Variable loads for } \\
\text { annual } \\
\text { savings. } \\
\quad \text { Constant } \\
\text { load. }\end{array}$ & $\begin{array}{l}33 \text { bus }-69 \\
\text { bus }-118 \text { bus }\end{array}$ & $\begin{array}{l}\text { Proposed > } \\
\text { QOTLBO } \\
>\text { TLBO }\end{array}$ & $\begin{array}{l}\text { Site } \\
\text { Size }\end{array}$ & - \\
\hline [32] & $\begin{array}{l}\text { QOCSOS (quasi- } \\
\text { oppositional } \\
\text { chaotic symbiotic } \\
\text { organisms search) }\end{array}$ & $\begin{array}{l}\text { SOS, KHA, } \\
\text { QOTLBO, } \\
\text { QOSIMBO-Q, } \\
\text { SFSA, AM- } \\
\text { PSO, EA-OPF }\end{array}$ & $\begin{array}{l}\text {-Real power loss } \\
\text {-Voltage profile } \\
\text {-Voltage stability }\end{array}$ & $\begin{array}{l}3 \text { DGs } \\
\mathrm{PF}=1-0,95 \text { lagging } \\
\text { and optimal. }\end{array}$ & $\begin{array}{l}33 \text { bus }-69 \text { bus } \\
-118 \text { bus }\end{array}$ & $\begin{array}{l}\text { QOCSOS }> \\
\text { SOS > } \\
\text { SFSA > } \\
\text { QOTLBO }\end{array}$ & $\begin{array}{l}\text { Site } \\
\text { Size }\end{array}$ & - \\
\hline [33] & Comparative study & $\begin{array}{l}\text { PSO, GWO, } \\
\text { BSA, WOA }\end{array}$ & Power loss & $\begin{array}{l}\text { P-type }(\mathrm{PF}=1), \mathrm{Q}- \\
\text { type }(\mathrm{PF}=0) \text { and } \\
\text { PQ-type }\end{array}$ & 33 bus & $\begin{array}{l}\mathrm{GWO}> \\
\mathrm{PSO}>\text { BSA } \\
>\text { WOA }\end{array}$ & \begin{tabular}{|l|} 
Site \\
Size \\
Open switches \\
\end{tabular} & - \\
\hline$[25]$ & $\begin{array}{l}\text { ALO (Ant Lion } \\
\text { Optimizer) }\end{array}$ & $\begin{array}{l}\text { Comparison } \\
\text { between } \\
\text { different DG } \\
\text { configuration }\end{array}$ & $\begin{array}{l}\text {-Voltage stability } \\
\text {-Active power loss } \\
\text {-Reactive power loss }\end{array}$ & $\begin{array}{l}\mu \mathrm{T}, \text { wind, } \mathrm{PV} \\
\text { with synchronous } \\
\text { condensers }\end{array}$ & 118 bus & $\begin{array}{ll}-- \\
\end{array}$ & \begin{tabular}{|l|} 
Sit \\
Size
\end{tabular} & - \\
\hline$[34]$ & \begin{tabular}{|l|} 
EGA \\
(Elitism Genetic \\
Algorithm) \\
\end{tabular} & PSO, GA & $\begin{array}{l}\text {-Electricity } \\
\text { production } \\
\text {-Investment cost }\end{array}$ & $\begin{array}{l}\text { Wind, PV and EESS } \\
\text { (distributed } \\
\text { microgrid) }\end{array}$ & ----- & $\begin{array}{c}\text { EGA }>\text { PSO } \\
>\text { GA }\end{array}$ & $\begin{array}{l}\text { Site } \\
\text { Size }\end{array}$ & - \\
\hline [35] & Comparative study & $\begin{array}{lr}\text { TS, } \\
\text { (scatter } \\
\text { search), }\end{array}$ & Active power loss & $\begin{array}{l}3 \text { DGs with variable } \\
\text { PF }\end{array}$ & IEEE 13 bus & $\begin{array}{c}\mathrm{SS}>\mathrm{TS}> \\
\mathrm{AC}\end{array}$ & $\begin{array}{l}\text { Site } \\
\text { Size }\end{array}$ & - \\
\hline$[36]$ & ALO & PSO, GA & $\begin{array}{l}\text { Purchased energy } \\
\text { Cost } \\
\text {-Reliability } \\
\text {-DG's application } \\
\text { cost } \\
\text {-Distribution system } \\
\text { loss } \\
\text {-Voltage deviation } \\
\end{array}$ & $\begin{array}{l}2 \text { different type } \\
\text { DG for each network. }\end{array}$ & 33 bus -69 bus & $\begin{array}{c}\mathrm{ALO}>\mathrm{PSO} \\
>\text { GA }\end{array}$ & $\begin{array}{l}\text { Site } \\
\text { Size }\end{array}$ & - \\
\hline [37] & $\begin{array}{l}\text { CSA (cuckoo } \\
\text { search algorithm) }\end{array}$ & PSO, GA & $\begin{array}{l}\text {-Power loss } \\
\text {-Voltage deviations } \\
\text {-Voltage variations }\end{array}$ & $\begin{array}{l}4 \text { P-type DGs from } \\
10 \text { to } 40 \text { MW with a } \\
\text { constant power } \\
\text { generation. }\end{array}$ & 38 bus- 69 bus & $\begin{array}{c}\mathrm{CSA}>\mathrm{GA} \\
>\mathrm{PSO}\end{array}$ & Site & - \\
\hline$[38]$ & GWO & GA & $\begin{array}{l}\text {-Active power loss } \\
\text {-Voltage profile } \\
\end{array}$ & $\begin{array}{l}\text { Test with } 1,2,3 \text { and } 4 \\
\text { DGs }\end{array}$ & 33 bus- 69 bus & GWO $>$ GA & \begin{tabular}{|l|} 
Site \\
Size \\
\end{tabular} & - \\
\hline [39] & PSO & $\begin{array}{l}\text { Not a } \\
\text { comparative } \\
\text { study }\end{array}$ & \begin{tabular}{|l|} 
THD \\
-Total power loss \\
-Total cost of DG \\
-Green house gas \\
emissions \\
-Voltage profile
\end{tabular} & $\begin{array}{l}\text {-Wind, PV, Fuel } \\
\text { Cell. } \\
\text {-Variant PF. } \\
\text {-Linear and non } \\
\text { linear load. }\end{array}$ & 31 bus & $\begin{array}{l}\text { Optimal size } \\
\text { and location } \\
\text { give best } \\
\text { results. }\end{array}$ & $\begin{array}{l}\text { Site } \\
\text { Size }\end{array}$ & $\begin{array}{l}\text {-Load growth } \\
\text {-Profile of } \\
\text { solar } \\
\text { irradiation. } \\
\text {-Wind speed } \\
\text {-Load demand } \\
\text { variations. } \\
\end{array}$ \\
\hline [24] & $\begin{array}{l}\text { HHSA (Hybrid } \\
\text { HAS + PABCA) }\end{array}$ & HAS & $\begin{array}{l}\text { Power loss } \\
\text { Voltage profile }\end{array}$ & $\begin{array}{l}\text { DG + Shunt } \\
\text { capacitors, } \\
1,2 \text { and } 3 \text { DGs }\end{array}$ & 33bus-119 bus & HHSA $>$ HAS & $\begin{array}{l}\text { Site } \\
\text { Size }\end{array}$ & - \\
\hline [40] & DEA & $\begin{array}{l}\mathrm{CF}-\mathrm{PSO}, \\
\mathrm{HCF}, \quad \mathrm{IA}, \\
\mathrm{CPLS}\end{array}$ & $\begin{array}{l}\text {-Distribution system } \\
\text { loss } \\
\text {-Total voltage } \\
\text { deviation. } \\
\text {-Voltage stability } \\
\text { index }\end{array}$ & $\begin{array}{l}\text {-Constant and } \\
\text { variable loads and } \\
\text { generation. } \\
\text {-1,2 and } 3 \text { DGs. } \\
\text {-Real time DG } \\
\text { operation with } \\
\text { optimal PF. }\end{array}$ & - & $\begin{array}{l}\text { DEA }>\text { CF-PSO } \\
>\text { IA }>\text { CPLS }\end{array}$ & $\begin{array}{l}\text { Site } \\
\text { Size } \\
\text { PF }\end{array}$ & - \\
\hline [26] & LSA & $\begin{array}{l}\text { BFOA, } \\
\text { QOTLBO, } \\
\text { PSO, BSOA }\end{array}$ & $\begin{array}{l}\text {-Power loss } \\
\text {-Total voltage } \\
\text { deviation } \\
\text {-Voltage stability } \\
\text { index. }\end{array}$ & $\begin{array}{l}\text { DG + DSTATCOM } \\
\text { Variable load }\end{array}$ & 33 bus- 69 bus & $\begin{array}{l}\text { LSA gives best } \\
\text { results }\end{array}$ & $\begin{array}{l}\text { Site } \\
\text { Size }\end{array}$ & - \\
\hline
\end{tabular}


Table 3. (Continued)

\begin{tabular}{|c|c|c|c|c|c|c|c|c|}
\hline Ref & $\begin{array}{l}\text { Proposed } \\
\text { algorithm }\end{array}$ & Compared to & Objective functions & $\begin{array}{l}\text { DG type / number / } \\
\text { configuration }\end{array}$ & Network & results & $\begin{array}{l}\text { Decision } \\
\text { variables }\end{array}$ & Uncertainties \\
\hline [41] & $\begin{array}{l}\text { MICA } \\
\text { (Modified } \\
\text { ICA) }\end{array}$ & CSA & $\begin{array}{l}\text {-Active power loss } \\
\text {-Voltage stability }\end{array}$ & $\begin{array}{l}\text { PQ-type with load } \\
\text { variation. }\end{array}$ & 34 bus-69bus & MICA $>$ CSA & $\begin{array}{l}\text { Site } \\
\text { Size }\end{array}$ & - \\
\hline [42] & $\begin{array}{l}\text { RTO (Rooted } \\
\text { Tree } \\
\text { Optimization) }\end{array}$ & PSO, DE & $\begin{array}{l}\text {-Index of voltage } \\
\text { profile. } \\
\text {-Index of loss } \\
\text { reduction. } \\
\text {-Index of pollution } \\
\text { reduction. }\end{array}$ & $\begin{array}{l}\text {-DG+DSTATCOM } \\
\text {-PV DG } \\
\text {-Variable load }\end{array}$ & 33 bus & $\begin{array}{l}\mathrm{RTO}>\mathrm{PSO}> \\
\mathrm{DE}\end{array}$ & Site & - \\
\hline [43] & $\begin{array}{l}\text { Hybrid } \\
\text { ALOA+LSF }\end{array}$ & $\begin{array}{l}\text { ALOA, } \\
\text { BSOA, } \\
\text { EVPSO, } \\
\text { PSOPC, } \\
\text { ADPSO, } \\
\text { DAPSO. }\end{array}$ & $\begin{array}{l}\text {-Active power losses } \\
\text {-Voltage profile } \\
\text {-Voltage stability } \\
\text { index }\end{array}$ & $\begin{array}{l}\text {-Wind + PV } \\
-1 \text { DG and } 2 \text { DG. } \\
\text {-Load variation }\end{array}$ & 34 bus-69bus & $\begin{array}{l}\text { ALOA }> \\
\text { ADPSO } \\
>\text { DAPSO }> \\
\text { BSOA }> \\
\text { analytical }> \\
\text { PSOPC }> \\
\text { EVPSO }\end{array}$ & $\begin{array}{l}\text { Site } \\
\text { Size }\end{array}$ & - \\
\hline [44] & $\begin{array}{l}\text { Hybrid } \\
\text { PSO+analytical } \\
\text { approach }\end{array}$ & $\begin{array}{l}\text { Analytical } \\
\text { approach, } \\
\text { PSO }\end{array}$ & - Active power loss. & $\begin{array}{l}\text { PDG, QDG, PQDG } \\
\text { (lagging), PQDG } \\
\text { (leading). }\end{array}$ & 41 bus & $\begin{array}{l}\text { Proposed }> \\
\text { PSO > } \\
\text { Analytical } \\
\end{array}$ & $\begin{array}{l}\text { Site } \\
\text { Size }\end{array}$ & - \\
\hline [45] & $\begin{array}{l}\text { PSO (with } \\
\text { AHP for } \\
\text { defining } \\
\text { weight factors } \\
\text { of objective } \\
\text { functions) }\end{array}$ & $\begin{array}{l}\text { Comparison } \\
\text { is made in } \\
\text { terms of } \\
\text { application } \\
\text { of AHP for } \\
\text { deciding } \\
\text { weight } \\
\text { factors }\end{array}$ & $\begin{array}{l}\text {-Power loss } \\
\text {-Voltage deviation. } \\
\text {-Environment impact } \\
\text { reduction index. } \\
\text {-Economic index. }\end{array}$ & $\begin{array}{l}\text { Wind, } \mathrm{PV} \text {, } \\
\text { Biomass. } \\
\mathrm{PF}=1 \text { and } 0,95 \\
\text { (lagging) }\end{array}$ & $\begin{array}{l}51 \mathrm{bus} \\
11 \mathrm{kV}\end{array}$ & $\begin{array}{l}\text { With AHP } \\
\text { deciding weight } \\
\text { factors, results } \\
\text { are the best. }\end{array}$ & $\begin{array}{l}\text { Site } \\
\text { Size }\end{array}$ & $\begin{array}{l}\text { Intermittency } \\
\text { modeling of } \\
\text { Wind and PV } \\
\text { generated } \\
\text { power. }\end{array}$ \\
\hline [46] & $\begin{array}{l}\text { MOMSOS } \\
\text { (Multi- } \\
\text { Objective } \\
\text { Modified } \\
\text { Symbiotic } \\
\text { Organism } \\
\text { Search) }\end{array}$ & $\begin{array}{l}\text { MOSOS, } \\
\text { NSGAII, } \\
\text { MOPSO. }\end{array}$ & $\begin{array}{l}\text { - Annual energy loss. } \\
\text { - Annual investment } \\
\text { and operating cost. } \\
\text { - Annual electricity } \\
\text { purchase cost. } \\
\text { - Total Voltage } \\
\text { deviation. }\end{array}$ & $\begin{array}{l}\text { Wind, PV and } \\
\text { Biomass. }\end{array}$ & 69 bus & $\begin{array}{l}\text { MOMSOS }> \\
\text { NSGAII }> \\
\text { MOSOS }> \\
\text { MOPSO }\end{array}$ & $\begin{array}{l}\text { Site } \\
\text { Size }\end{array}$ & - \\
\hline [11] & $\begin{array}{l}\text { Hybrid } \\
\text { CSA+PSO } \\
\text { (Crow search } \\
\text { algorithm + } \\
\text { PSO) }\end{array}$ & $\begin{array}{l}\text { TLBO, } \\
\text { PSO, } \\
\text { PSOGSA( } \\
\text { Phasor } \\
\text { PSO+GSA). }\end{array}$ & $\begin{array}{l}\text { - Total cost } \\
\text { - Transmission } \\
\text { Power loss. }\end{array}$ & $\begin{array}{l}\text { Wind, PV } \\
1,2 \text { and } 3 \text { DGs }\end{array}$ & 30 bus & $\begin{array}{l}\text { CSA-PSO }> \\
\text { PPSOGSA }> \\
\text { TLBO }>\text { PSO }\end{array}$ & $\begin{array}{l}\text { Site } \\
\text { Size }\end{array}$ & - \\
\hline [28] & PPSOGSA & $\begin{array}{l}\text { PPSO, } \\
\text { GSA, MFO, } \\
\text { GA, DE, } \\
\text { TLBO, } \\
\text { MSA,CS, } \\
\text { BSA, } \\
\text { SRSR, ICA, } \\
\text { FFA and } \\
\text { others }\end{array}$ & $\begin{array}{l}\text { - Active power loss. } \\
\text { - Load bus voltage } \\
\text { deviation. } \\
\text {-Total cost of fuel. }\end{array}$ & Wind, PV & 30 bus & $\begin{array}{l}\text { PPSOGSA }> \\
\text { WDO }>\text { others }\end{array}$ & \begin{tabular}{|l}
$-\mathrm{PF}$ \\
- Voltage \\
magnitude
\end{tabular} & $\begin{array}{l}\text { - Wind speed. } \\
\text {-Solar } \\
\text { irradiation. }\end{array}$ \\
\hline [47] & $\begin{array}{l}\text { Fuzzy based } \\
\text { extended } \\
\text { NSGA II (E- } \\
\text { NSGA II) }\end{array}$ & $\begin{array}{l}\text { SPEA, } \\
\text { MOGA, } \\
\text { MOPSO, } \\
\text { NSGA II, } \\
\text { MOEA/D. }\end{array}$ & $\begin{array}{l}\text {-Voltage profile. } \\
\text {-Benefit cost } \\
\text { maximization. } \\
\text {-Environmental } \\
\text { benefit. }\end{array}$ & $\begin{array}{l}\text { PV, Battery storage } \\
\text { system (BSS), } \\
\text { DSTATCOM. }\end{array}$ & 69 bus & $\begin{array}{l}\text { E-NSGA II > } \\
\text { MOEA/D > } \\
\text { NSGA II > } \\
\text { MOPSO > } \\
\text { SPEA > } \\
\text { MOGA }\end{array}$ & $\begin{array}{l}\text { Site } \\
\text { Size } \\
\text { Number }\end{array}$ & $\begin{array}{l}\text { PV power } \\
\text { generation. }\end{array}$ \\
\hline [48] & $\begin{array}{l}\text { APSO } \\
\text { (Adaptive } \\
\text { PSO) } \\
\text { MSGA } \\
\text { (Modified } \\
\text { GSA) }\end{array}$ & \begin{tabular}{|l|} 
AEO \\
(Artificial \\
Ecosystem- \\
based \\
Optimization)
\end{tabular} & $\begin{array}{l}\text {-Power losses. } \\
\text {-Voltage stability. } \\
\text {-Voltage deviation. }\end{array}$ & $\begin{array}{l}\text { Single and multiple } \\
\text { DGs, with unity and } \\
\text { optimal PF. }\end{array}$ & 69 bus -85 bus. & $\begin{array}{l}\text { MGSA > } \\
\text { APSO > AEO }>\end{array}$ & $\begin{array}{l}\text { Site } \\
\text { Size } \\
\text { PF }\end{array}$ & - \\
\hline
\end{tabular}

From Table 3, the most technical objective functions used are: voltage profile improvement and losses reduction, with a very relevant consideration of the reliability enhancement $[36,56]$. For the economic consideration, most authors prefer cost of benefit maximisation or profit maximisation, taking into account inflation and interest rates [57]. Furthermore, to assess the environmental benefit of integrating the RDG into the distribution network, researchers recommend the reduction of greenhouse gas (GHG) emissions [58].

All these objectives are generally subject to the constraint of power balance, voltage and temperature limits. However, many approaches have been developed to address these constraints. The penalty-based system is the most widely adopted mechanism for effectively 
handling constraints in the corresponding adaptation function [46].

From Table 3, it can easily be concluded that the most opportune path is the hybrid approach $[43,49]$. Most authors have proven the effectiveness of this choice. The most important task is to raise the drawbacks of each method and try to overcome it with another method that does not have the same drawbacks. Table 4 provides the authors with the common drawbacks and advantages of all meta-heuristic methods.

Table 4. Meta-heuristic's Prons and Cons [8,53-55].

\begin{tabular}{|l|l|}
\hline \multicolumn{1}{|c|}{ Advantages } & \multicolumn{1}{|c|}{ Drawbacks } \\
\hline -Efficient performance & -High complexity. \\
-Need for fewer iteration & -Premature convergence. \\
-Capability to analyse & -Instability. \\
large-scale systems. & -Tuning parameters. \\
-The presence of a very rich & -Slightly difficult coding. \\
knowledge base. & \\
-Effortlessly parallelizable, \\
i.e. more suited for parallel \\
computation. the \\
-Good concerning the \\
exploration and the \\
exploration of the search \\
space and the identification \\
of areas with high quality \\
solutions.
\end{tabular}

Referring to the No Free Lunch (NFL) theorem, there is no perfect method to solve all optimization problems [50]. Thus, the quality of the solution and the computational complexity remains a very difficult tradeoff, which cannot easily be compromised. From the Table 4 the most critical drawback of meta-heuristic methods is parameter tuning. So the most recommended method, is the parameter-free one $[51,52]$.

\section{Conclusions}

Meta-heuristic approaches are increasingly attracting researchers. Certainly the ORDGAP problem will become one of the most important axes in the field of renewable energy. This article proves this fact through a brief review of recent research work in this field. That said, the use of meta-heuristic methods will build a global vision on the future electricity grid.

On the basis of this literature review, the most important recommendations for this scope of research can be listed as follows:

- The power generation based renewable sources, type of load and fluctuations in the electricity market, in addition to several other uncertain parameters, are principal causes of intermittencies. Thus, integrating uncertainties for modelling several parameters is strongly recommended for well-addressing the ORDGAP problem.

- Hybridization is also the most recommended path that can be used, to overcome drawbacks of meta-heuristic methods.
- The operation of the DG in autonomous manner could also lead to an extension of future research coverage.

- The introduction of new free-parameter algorithms, can also enhance the relevance of the obtained results, and reduce the complexity issue.

- The criteria for comparing the different algorithms are not discussed in this article. It is therefore strongly recommended to review the testing and comparison methods adopted in the literature.

- For the sake of brevity, this article does not introduce the adopted mathematical formulations of all objective functions and constraints. The choice of these formulations is a rather preponderant step to successfully solve the ORDGAP problem. Thus, exhaustive review of these formulas could be quite beneficial for all researchers and decision-makers.

- The research work can be complemented by the distribution system planning considering the intermittent nature of renewable sources. This includes stochastic studies, probabilistic and possibilistic models for the power produced by this kind of sources, as well as uncertainties related to load growth.

\section{References}

1. U.S. Energy Information Administration, "EIA." [Online]. Available: https://www.eia.gov/.

2. C. Vezzoli et al., "Designing Sustainable Energy for All. Sustainable Product-Service System Design Applied to Distributed Renewable Energy," in Designing Sustainable Energy for All, 1st ed., Springer Nature Switzerland, 2018, p. 230.

3. L. Mehigan, J. P. Deane, B. P. Ó. Gallachóir, and V. Bertsch, "A review of the role of distributed generation (DG) in future electricity systems," Energy, vol. 163, pp. 822-836, 2018.

4. Q. Volker, Rethinking Energy: Renewable Energy and Climate Change, 1st ed. Berlin, Germany: IEEE PRESS, 2010.

5. A. Tarraq, F. Elmariami, and T. Haidi, "Distributed Renewable Energy Generation: A state-of-art of different planning methods," in Doctoral Days in Engineering Sciences, 2nd edition, Casablanca, Morocco, 2019, no. June.

6. W. L. Theo, J. S. Lim, W. S. Ho, H. Hashim, and C. T. Lee, "Review of distributed generation (DG) system planning and optimisation techniques: Comparison of numerical and mathematical modelling methods," Renew. Sustain. Energy Rev., vol. 67, pp. 531-573, 2016.

7. A. Rezaee Jordehi, "Allocation of distributed generation units in electric power systems: A review," Renew. Sustain. Energy Rev., vol. 56, pp. 893-905, 2016. 
8. A. Ehsan and Q. Yang, "Optimal integration and planning of renewable distributed generation in the power distribution networks: A review of analytical techniques," Appl. Energy, vol. 210, no. July 2017, pp. 44-59, 2017.

9. B. Singh and J. Sharma, "A review on distributed generation planning," Renew. Sustain. Energy Rev., vol. 76, no. March, pp. 529-544, 2017.

10. A. Bayat and A. Bagheri, "Optimal active and reactive power allocation in distribution networks using a novel heuristic approach," Appl. Energy, vol. 233-234, no. October 2018, pp. 71-85, 2019.

11. H. M. H. Farh, A. M. Al-Shaalan, A. M. Eltamaly, and A. A. Al-Shamma'A, "A Novel Crow Search Algorithm Auto-Drive PSO for Optimal Allocation and Sizing of Renewable Distributed Generation," IEEE Access, vol. 8, no. January, pp. 27807-27820, 2020.

12. J. H. Cho, Y. Wang, I. R. Chen, K. S. Chan, and A. Swami, "A Survey on Modeling and Optimizing Multi-Objective Systems," IEEE Commun. Surv. Tutorials, vol. 19, no. 3, pp. 1867-1901, 2017.

13. S. E. De Leon-Aldaco, H. Calleja, and J. Aguayo Alquicira, "Metaheuristic Optimization Methods Applied to Power Converters: A Review," IEEE Trans. Power Electron., vol. 30, no. 12, pp. 67916803, 2015.

14. Z. Abdmouleh, A. Gastli, L. Ben-Brahim, M. Haouari, and N. A. Al-Emadi, "Review of optimization techniques applied for the integration of distributed generation from renewable energy sources," Renew. Energy, vol. 113, no. November, pp. 266-280, 2017.

15. R. H. A. Zubo, G. Mokryani, H. S. Rajamani, J. Aghaei, T. Niknam, and P. Pillai, "Operation and planning of distribution networks with integration of renewable distributed generators considering uncertainties: A review," Renew. Sustain. Energy Rev., vol. 72, no. May 2016, pp. 1177-1198, 2017.

16. M. Pesaran H.A, P. D. Huy, and V. K. Ramachandaramurthy, "A review of the optimal allocation of distributed generation: Objectives, constraints, methods, and algorithms," Renew. Sustain. Energy Rev., vol. 75, no. October, pp. 293312, 2016.

17. T. Ackermann, A. Göran, and L. Söder, "Distributed generation- a definition .pdf," Electr. Power Syst. Res., vol. 57, pp. 195-204, 2001.

18. W. El-Khattam and M. M. A. Salama, "Distributed generation technologies, definitions and benefits," Electr. Power Syst. Res., vol. 71, no. 2, pp. 119-128, 2004.

19. T. Abdel-Galil and A. Abu-Elanien, "Protection coordination planning with distributed generation," Varennes, 2007.

20. D. Q. Hung, N. Mithulananthan, and R. C. Bansal, "Analytical expressions for DG allocation in primary distribution networks," IEEE Trans. Energy Convers., vol. 25, no. 3, pp. 814-820, 2010.
21. K. S. Sambaiah, "A Review on Optimal Allocation and Sizing Techniques for DG in Distribution Systems," Int. J. Renew. ENERGY Res., vol. 8, no. 3, 2018.

22. A. K. Bohre, G. Agnihotri, and M. Dubey, "Optimal sizing and sitting of DG with load models using soft computing techniques in practical distribution system," IET Gener. Transm. Distrib., vol. 10, no. 11, pp. 2606-2621, 2016.

23. M. Khalid, U. Akram, and S. Shafiq, "Optimal planning of multiple distributed generating units and storage in active distribution networks," IEEE Access, vol. 6, no. September, pp. 55234-55244, 2018.

24. K. Muthukumar and S. Jayalalitha, "Optimal placement and sizing of distributed generators and shunt capacitors for power loss minimization in radial distribution networks using hybrid heuristic search optimization technique," Int. J. Electr. Power Energy Syst., vol. 78, pp. 299-319, 2016.

25. A. R. Abul'Wafa, "Ant-lion optimizer-based multiobjective optimal simultaneous allocation of distributed generations and synchronous condensers in distribution networks," Int. Trans. Electr. Energy Syst., no. September, pp. 1-14, 2018.

26. Y. Thangaraj and R. Kuppan, "Multi-objective simultaneous placement of DG and DSTATCOM using novel lightning search algorithm," J. Appl. Res. Technol., vol. 15, no. 5, pp. 477-491, 2017.

27. C. A. C. Coello, "An Updated Survey of GA-Based Multiobjective Optimization Techniques," ACM Comput. Surv., vol. 32, no. 2, pp. 109-143, 2000.

28. Z. Ullah, S. Wang, and J. Radosavljević, “A Novel Method Based on PPSO for Optimal Placement and Sizing of Distributed Generation," IEEJ Trans. Electr. Electron. Eng., vol. 14, no. 12, pp. 17541763, 2019.

29. M. C. V. Suresh and J. B. Edward, "A hybrid algorithm based optimal placement of DG units for loss reduction in the distribution system," Appl. Soft Comput.J., vol. 91, p. 106191, 2020.

30. Y. Ding, L. Chen, and K. Hao, Bio-inspired optimization algorithms, vol. 118. 2018.

31. I. A. Quadri, S. Bhowmick, and D. Joshi, "A comprehensive technique for optimal allocation of distributed energy resources in radial distribution systems," Appl. Energy, vol. 211, no. November 2017, pp. 1245-1260, 2018.

32. K. H. Truong, P. Nallagownden, I. Elamvazuthi, and D. N. Vo, "A Quasi-Oppositional-Chaotic Symbiotic Organisms Search algorithm for optimal allocation of DG in radial distribution networks," Appl. Soft Comput.J., vol. 88, p. 106067, 2020.

33. A. Rezaee.Jordehi, "DG allocation and reconfiguration in distribution systems by metaheuristic optimisation algorithms: A comparative analysis," in Proceedings - 2018 IEEE PES Innovative Smart Grid Technologies Conference Europe, ISGT-Europe 2018, 2018, pp. 1-6. 
34. R. Shi, C. Cui, K. Su, and Z. Zain, "Comparison study of two meta-heuristic algorithms with their applications to distributed generation planning," Energy Procedia, vol. 12, pp. 245-252, 2011.

35. L. Lopez, J. Doria-Garcia, C. Pimienta, and A. Arango-Manrique, "Distributed Generation Allocation and Sizing: A Comparison of Metaheuristics Techniques," in 2019 IEEE International Conference on Environment and Electrical Engineering and 2019 IEEE Industrial and Commercial Power Systems Europe (EEEIC / I\&CPS Europe), 2019, pp. 1-6.

36. M. J. Hadidian-Moghaddam, S. Arabi-Nowdeh, M. Bigdeli, and D. Azizian, "A multi-objective optimal sizing and siting of distributed generation using ant lion optimization technique," Ain Shams Eng. J., no. March, 2016.

37. Z. Moravej and A. Akhlaghi, "A novel approach based on cuckoo search for DG allocation in distribution network," Int. J. Electr. Power Energy Syst., vol. 44, no. 1, pp. 672-679, 2013.

38. A. Sobieh, M. Mandour, E. M. Saied, and M. M. Salama, "Optimal Number Size and Location of Distributed Generation Units in Radial Distribution Systems Using Grey Wolf Optimizer," Int. Electr. Eng. J., vol. 7, no. 9, pp. 2367-2376, 2017.

39. H. HassanzadehFard and A. Jalilian, "Optimal sizing and location of renewable energy based DG units in distribution systems considering load growth," Int. J. Electr. Power Energy Syst., vol. 101, no. February, pp. 356-370, 2018.

40. P. D. Huy, V. K. Ramachandaramurthy, J. Y. Yong, K. M. Tan, and J. B. Ekanayake, "Optimal placement, sizing and power factor of distributed generation: A comprehensive study spanning from the planning stage to the operation stage," Energy, vol. 195, p. 117011, 2020.

41. B. Poornazaryan, P. Karimyan, G. B. Gharehpetian, and M. Abedi, "Optimal allocation and sizing of DG units considering voltage stability, losses and load variations," Int. J. Electr. Power Energy Syst., vol. 79, pp. 42-52, 2016.

42. S. Sannigrahi and P. Acharjee, "Maximization of system benefits with the optimal placement of DG and DSTATCOM considering load variations," Procedia Comput. Sci., vol. 143, pp. 694-701, 2018.

43. E. S. Ali, S. M. Abd Elazim, and A. Y. Abdelaziz, "Ant Lion Optimization Algorithm for optimal location and sizing of renewable distributed generations," Renew. Energy, vol. 101, pp. 13111324, 2017.

44. T. S. Tawfeek, A. H. Ahmed, and S. Hasan, "Analytical and particle swarm optimization algorithms for optimal allocation of four different distributed generation types in radial distribution networks," Energy Procedia, vol. 153, pp. 86-94, 2018.

45. S. S. Tanwar and D. K. Khatod, "Techno-economic and environmental approach for optimal placement and sizing of renewable DGs in distribution system,"
Energy, vol. 127, pp. 52-67, 2017.

46. S. Saha and V. Mukherjee, "A novel multi-objective modified symbiotic organisms search algorithm for optimal allocation of distributed generation in radial distribution system," Neural Comput. Appl., vol. 6, 2020.

47. S. Roy Ghatak, S. Sannigrahi, and P. Acharjee, "Multi-Objective Approach for Strategic Incorporation of Solar Energy Source, Battery Storage System, and DSTATCOM in a Smart Grid Environment," IEEE Syst. J., vol. 2, pp. 1-12, 2018.

48. A. Eid, "Allocation of distributed generations in radial distribution systems using adaptive PSO and modified GSA multi-objective optimizations," Alexandria Eng. J., no. September, 2020.

49. A. Tzanetos and G. Dounias, "Nature inspired optimization algorithms or simply variations of metaheuristics?," Artif. Intell. Rev., no. 0123456789, 2020.

50. D. H. Wolpert and W. G. Macready, "No Free Lunch Theorems for Optimization," IEEE Trans. Evol. Comput., vol. 1, no. 1, pp. 67-82, 1997.

51. K. S. Sambaiah, “A Review on Optimal Allocation and Sizing Techniques for DG in Distribution Systems," no. October, 2018.

52. S. Q. Salih and A. A. Alsewari, "A new algorithm for normal and large-scale optimization problems: Nomadic People Optimizer," Neural Comput. Appl., vol. 1, 2019.

53. C. Blum, J. Puchinger, G. R. Raidl, and A. Roli, "Hybrid metaheuristics in combinatorial optimization: A survey," Appl. Soft Comput. J., vol. 11, no. 6, pp. 4135-4151, 2011.

54. N. D. Mirza Šarić1, Jasna Hivziefendić, "Distributed Generation Allocation: Objectives, Constraints and Methods," in Advanced Technologies, Systems, and Applications III, 3th ed., vol. 1, S. Avdaković, Ed. Springer Nature Switzerland, 2019, pp. 132-149.

55 R. Khokhar, S. Lalwani, and M. Lalwani, "A Simulation Study of Parallel Particle Swarm Optimization Algorithm for Proportional Integral Derivative Controller Tuning," India Int. Conf. Power Electron. IICPE, vol. 2018-Decem, pp. 1-4, 2018.

56. S. Roy Ghatak, S. Sannigrahi, and P. Acharjee, "Comparative performance analysis of DG and DSTATCOM using improved pso based on success rate for deregulated environment," IEEE Syst. J., vol. 12, no. 3, pp. 2791-2802, 2017.

57. R. Payasi, A. Singh, and D. Singh, "Review of distributed generation planning: objectives, constraints, and algorithms," Int. J. Eng. Sci. Technol., vol. 3, no. 3, 2011.

58. A. S. Dagoumas and N. E. Koltsaklis, "Review of models for integrating renewable energy in the generation expansion planning," Appl. Energy, vol. 242, no. December 2018, pp. 1573-1587, 2019. 